\author{
Romain Jouffroy \\ Lionel Lamhaut \\ Mihaela Petre Soldan \\ Benoit Vivien \\ Pascal Philippe \\ Kim An \\ Pierre Carli
}

\section{A new approach for early onset cardiogenic shock in acute colchicine overdose: place of early extracorporeal life support (ECLS)?}

Accepted: 17 March 2013

Published online: 24 April 2013

(C) Springer-Verlag Berlin Heidelberg and ESICM 2013

Dear Editor,

Colchicine belongs to the family of

spindle poisons, which are mainly

used to treat and prevent forms of

microcrystalline arthritis, such as gout. It has a narrow therapeutic index. Colchicine overdose is associated with a high mortality rate [1]. Early symptoms usually include gastrointestinal pain; multiorgan failure typically occurs next, alongside metabolic derangements and bone marrow suppression. Prognostic factors include a supposed ingested dose of $>0.8 \mathrm{mg} / \mathrm{kg}$, cardiogenic shock, and ARDS [1]. Death from acute colchicine poisoning is usually due to hemodynamic collapse and cardiac arrhythmias.

A 51-year-old male pharmacist (medical history of depression, high blood pressure, and gout treated with colchicine) was admitted to the ICU for an acute and unexplained circulatory shock. Over the course of his admission he continued to deteriorate and required high doses of norepinephrine $(4.2 \mu \mathrm{g} / \mathrm{kg} / \mathrm{min})$, epinephrine $(0.4 \mu \mathrm{g} / \mathrm{kg} / \mathrm{min})$, and dobutamine $(10 \mu \mathrm{g} / \mathrm{kg} / \mathrm{min})$. After the first $24 \mathrm{~h}$, his wife found a bottle of $1 \mathrm{mg}$ Colchimax (17 tablets missing). The patient then admitted to ingesting those tablets, which was later confirmed by laboratory investigations: $9.7 \mathrm{nmol} / \mathrm{L}$ at day $1 ; 9.25 \mathrm{nmol} / \mathrm{L}$ at day $3 ; 5.75 \mathrm{nmol} / \mathrm{L}$ at day 6 ; and less than $1.25 \mathrm{nmol} / \mathrm{L}$ at day 16 . Following the confirmation of a colchicine overdose, the patient's clinical condition worsened. He quickly developed multiorgan failure and was hemodynamically unstable. In the ICU, it was decided to resort to a bedside-to-bench process. For the following 10 days he received extracorporeal life support (ECLS) (CARDIOHELP, Maquet, Rastatt, Germany), which was achieved through femoral venous arterial cannulation surgery with an initial rate of $3 \mathrm{~L} / \mathrm{min}, 3,700 \mathrm{rev} / \mathrm{min}$. He made a good recovery and showed normal organ function by day 6 . The ECLS was removed on day 10 and the mechanical ventilator on day 20 . He did not present any hematological failure. He suffered from an acute renal failure due to tubular necrosis that required dialysis for 36 days. The patient was discharged on day 52 with a CPC score of 1 .

Recent studies have proved that human [1] and animal [2] immunotherapy antibodies can be successfully used to treat colchicine overdose. However, there are a few limitations on the use of immunotherapy antibodies:

- Availability

- Timeframe between ingestion and admission

- Dosage issues

- High costs of preclinical trials

The initial colchicine plasma counts were low because it was $48 \mathrm{~h}$ after the apparent overdose, or 5.5 colchicine plasma half-lives (over a $20-40 \mathrm{~h}$ period [3]). Since there is no specific treatment available for colchicine poisoning, aggressive organ support remains the only option to treat it. ECLS is usually indicated in cases of acute toxin-related heart failure when patients are not responding to conventional treatments.

Extracorporeal life support should also be considered in the early stage of refractory shock when colchicine ingestion is confirmed or suspected [4], as it is the most cost-effective treatment. There has been one reported case of a colchicine overdose that required an ECLS but ended with death [5]. Our case seems to be the first time that an ECLS was successfully used to save a patient who presented with multiple organ failure caused by colchicine poisoning.

\section{References}

1. Bismuth C, Conso F (1977) Medullary aplasia after acute colchicine poisoning. 20 cases. Nouv Presse Med 7(6):1625-1629

2. Baud FJ, Sabouraud A, Vicaut E, Taboulet P, Lang J, Bismuth C, Rouzioux JM, Scherrmann JM (1995)

Brief report: treatment of severe colchicine overdose with colchicinespecific Fab fragments. N Engl J Med 9(332):642-645

3. Rochdi M, Sabouraud A, Baud FJ, Bismuth C, Scherrmann JM (1992) Toxicokinetics of colchicine in humans: analysis of tissue, plasma and urine data in ten cases. Hum Exp Toxicol 11:510-516

4. Mégarbane B, Deye N, Baud FJ (2008) Extracorporeal life support for poisonings with cardiotoxicants. Rev Prat 30(58):855-860

5. Lainé M, Mourissoux G, Camou F (2012) Early onset cardiogenic shock in acute colchicine overdose. J Clin Toxicol 2:134

R. Jouffroy $(\bowtie) \cdot$ L. Lamhaut · M. Petre Soldan · B. Vivien · P. Philippe

K. An · P. Carli

Hôpital Necker Enfants Malades,

Anesthésie Réanimation, SAMU,

Paris, France

e-mail: romain.jouffroy@nck.aphp.fr 